\title{
DIFFERENTIAL EFFECT OF FOREIGN CAPITAL AND CAPITAL GROWTH IN GHANA
}

Philomena Dadzie, University of Professional Studies, Accra, Ghana

Richard Stephens Cromwell, University of Professional Studies, Accra, Ghana

dx.doi.org/10.18374/JABE-20-3.7

\begin{abstract}
Ghana has initiated various policies to attract foreign capital and this has increased the inflow of capital into Ghana. The key issue addressed by the study is whether the dramatic increase in foreign capital inflows has resulted in the desired effect on economic growth in Ghana. The study aimed at examining the differential effect of foreign capital on economic growth in Ghana. Foreign direct investment (FDI), foreign aid, external debts and personal remittance was used to measure foreign capital whereas Gross Domestic Product (GDP) (constant, 2010) was used as a proxy for economic growth. Control variables are domestic capital, labor and trade openness. Data were obtained from World Development Indicator and Index mundi over the period of 1980-2018. The result showed that both foreign aid and FDI had a negative effect on economic growth whereas external debts and remittances had positive effect in the long run. In the short run, only foreign aid had a significant negative effect on GDP. The findings on causality suggest that there is a bi-directional causality between remittance and GDP whereas unidirectional causality running from FDI to GDP was identified. The study concluded that even in the presence of weak trade policy, external debts and remittance were seen to be significant growth-enhancing as compared to foreign direct investment and foreign aid. The study recommends that the government of Ghana should ensure proper allocation of foreign capital inflows into both physical and social infrastructure and should abstain from excessive dependent on government revenue.
\end{abstract}

Keywords: Economic growth, Foreign capital inflows, Gross Domestic Product 